\title{
NOTE
}

\section{NEW RECORDS FOR THREE SPECIES OF MONOGENEANS (PLATYHELMINTHES) OF MARINE FISHES IN THE GULF OF NICOYA, COSTA RICA}

\author{
Rogelio Aguilar-Aguilar ${ }^{1 *}$, Paula Marcotegui², Sergio Martorelli2 \& Luis García-Prieto ${ }^{3}$
}

1 Universidad Nacional Autónoma de México, Facultad de Ciencias, Departamento de Biología Comparada, Circuito Exterior s/n, Ciudad Universitaria, Ciudad de México, Apartado Postal 70-399, C. P. 04510 , Mexico. Email: raguilar@ciencias.unam.mx

${ }^{2}$ Consejo Nacional de Investigaciones Científicas y Técnicas-Universidad Nacional de La Plata, Centro de Estudios Parasitológicos y de Vectores, Boulevard 120 s/n e/61 y 62, 1900, La Plata, Buenos Aires, Argentina 3Universidad Nacional Autónoma de México, Instituto de Biología, Departamento de Zoología, Ciudad Universitaria, Ciudad de México, Apartado Postal 70-153, C. P. 04510, Mexico

${ }^{*}$ Corresponding author: raguilar@ ciencias.unam.mx

\begin{abstract}
Three monogenean taxa (Hargicola oligoplites, Mazocraes sp., and Neohexostoma euthynni) are recorded for marine fishes from the Gulf of Nicoya, Costa Rica. Two of them (Mazocraes sp. and $N$. euthynni) represent new records for the helminth fauna of Costa Rica.
\end{abstract}

Key words: Hargicola oligoplites, Mazocraes sp., Monogenea, Neohexostoma euthynni

\section{RESUMEN}

Nuevos registros para tres especies de monogeneos (Platyhelminthes) de peces marinos en el Golfo de Nicoya, Costa Rica. En esta contribución se registran tres taxones de monogeneos (Hargicola oligoplites, Mazocraes sp., and Neohexostoma euthynni) de peces marinos del Golfo de Nicoya, Costa Rica; de estas, Mazocraes sp. y $N$. euthynni representan nuevos registros para la fauna de Costa Rica.

Palabras clave: Hargicola oligoplites, Mazocraes sp., Monogenea, Neohexostoma euthynni

Costa Rica possesses a large tradition in the study of parasites of domestic and wildlife vertebrates (Solano-Trejos, 2010). However, the study of monogeneans has been relatively neglected; to date, only 23 species have been recorded parasitizing vertebrates in this country (Rodríguez-Ortíz et al., 2004). Type and voucher specimens of these records have been deposited in foreign collections, mainly at the Colección Nacional de Helmintos (CNHE), Mexico City, Mexico (Rodríguez-Ortiz et al., 2004). In this note, we examined some unidentified voucher specimens of monogeneans collected in Costa Rica, but deposited at CNHE, in order to establish the taxonomic identity of these worms, and to add new data about the diversity of this group of helminths in marine fishes from Costa Rica.

Monogeneans examined were found in 1982 from the fish species Oligoplites sp. (sierrita, leatherjacket), Anchovia macrolepidota (Kner, 1863) (sardinita, bigscale anchovy), and Euthynnus lineatus Kishinouye, 1920 (atún, black skipjack), collected from the Gulf of Nicoya, Costa Rica (Fig. 1). Site of collection was not geo-referred. Worms were stained and mounted in Canada balsam, then were deposited at CNHE remaining unidentified until now. We perform the taxonomic work for that material; once identified, each specimen was re-deposited at the CNHE.

The monogenean associated to Oligoplites sp. was identified as Hargicola oligoplites (Hargis, 1957) (Allodiscocotylidae, CNHE 9983, Figs. 2a and 2b). The specimen presents an elongated, asymmetrical body (2.99 $\mathrm{mm}$ long), width at level of vitellaria 0.23 $\mathrm{mm}$, mouth subterminal, pharynx ovoid ( 0.04 long by 0.03 wide), a pair of hemispherical buccal suckers in lateral funnel walls, 0.03 long by 0.02 wide; haptor no clearly separated from rest of body, with 3 clamps on the anterior edge (0.044-0.046 long by $0.052-0.055$ wide), and 4 clamps on the posterior (0.066-0.073 long by $0.068-0.073$ wide). End of the body armed with a pair of anchors (0.03 long). Vitellaria follicular, extending from level of seminal receptacles to anterior clamps. Egg 0.14 long by 0.06 wide, with filaments at both ends.

The identification of $H$. oligoplites was mainly based in the morphological features presented by Hargis (1957) in the original description of the species (as Vallisia oligoplites Hargis, 1957), but also in Bravo-Hollis (1989) and Takemoto et al. (1996). This monogenean species has been mainly recorded for carangid fishes of the genus Oligoplites from Mexico, Brazil and Costa Rica (Bravo-Hollis, 1989; Takemoto et al., 1996; RodríguezOrtiz et al., 2004; Cohen et al., 2013), and seems to be specific to this fish genus, even if has also been recorded for the serranid fish Epinephelus marginatus (Lowe, 1834) (Kohn et al., 1996). 


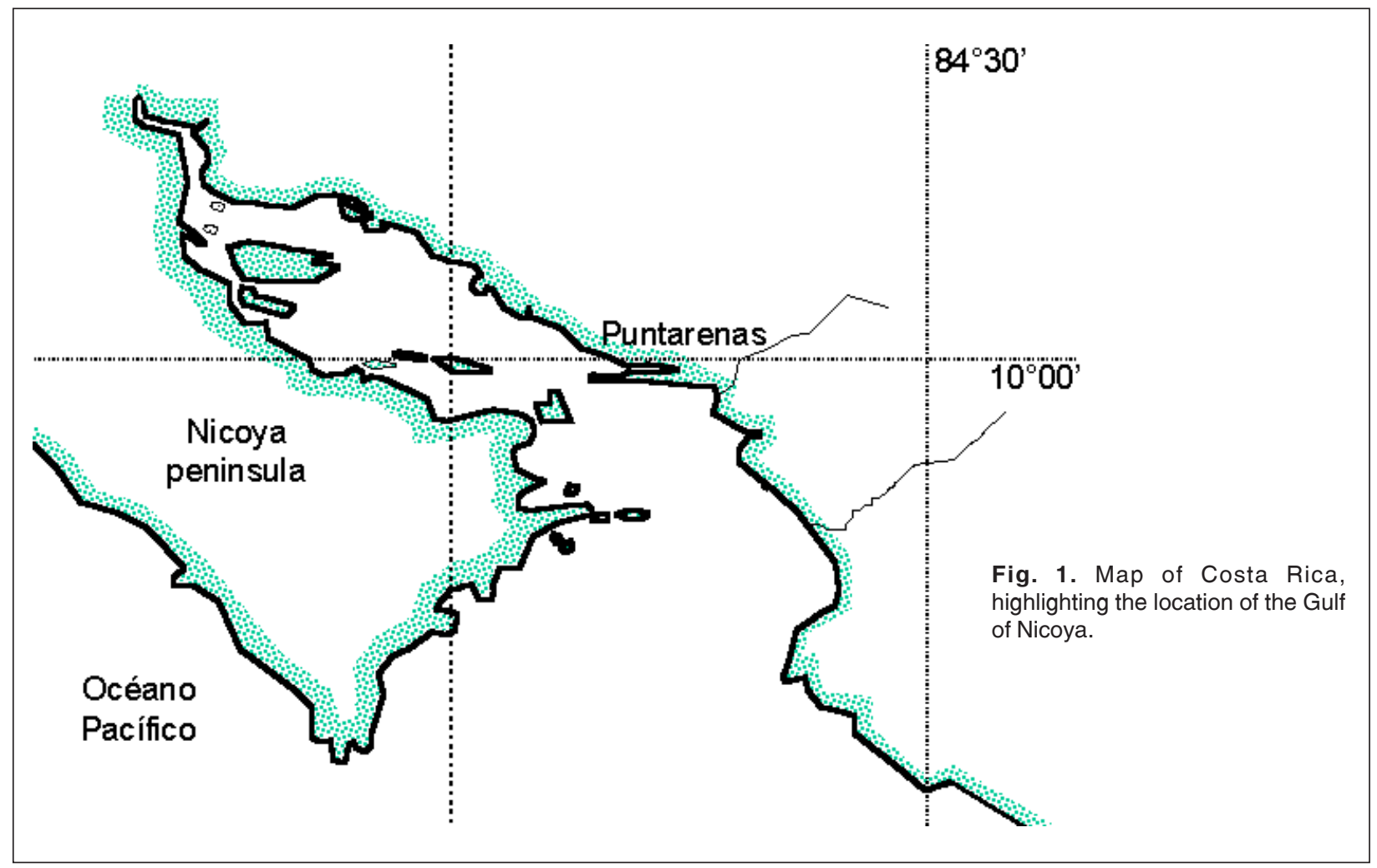

The specimen collected from $A$. macrolepidota is an unidentified species of the genus Mazocraes (Mazocraeidae, CNHE 9984, Fig. 2c and 2d). This specimen has an elongate body ( 0.77 long), tapering at anterior end ( 0.07 wide); haptor rounded $(0.16$ by 0.24 ), with four pairs of clamps, two anterior pairs 0.059-0.065 long by $0.067-0.07$ wide, two posterior pairs 0.045 by 0.062 . Buccal organs septate, $0.034-0.035$ long by 0.025-0.028 wide, open laterally to a subterminal buccal cavity. Pharynx almost oval ( 0.035 long by 0.029 wide).

Following to Timi et al. (1999), the morphologic traits of the studied specimen correspond to the genus Mazocraes. This genus is composed by seven species, which are parasites of clupeid or cyprinid fishes around the world (Bychowsky, 1961; Yamaguti, 1963; Reed et al., 2012; Chaudhary et al., 2013). The present record of Mazocraes sp. is the first for the engraulid fish Anchovia macrolepidota, and is also the first mention of this monogenean genus for Costa Rica. A previous record for Mazocraes in Engraulidae (as M. australis) was provided by Timi et al. (1999); however, some important morphological characteristics that would allow identifying the specimen studied at specific level are not evident in the material here studied.

The specimen from $E$. lineatus was identified as Neohexostoma euthynni (Meserve, 1938) (Hexostomatidae, CNHE 9985, Fig. 2e, $2 \mathrm{f}$ and 2g). This parasite has an elongated body (6.37 long by 0.55 at level of the haptor). Oral suckers 0.19 and 0.21 long by
0.20 wide, pharynx 0.4 long by 0.23 wide. Haptor with four pairs of suckers arranged in two longitudinal rows, three anteriormost pairs co-equal (0.134-0.137 long by 0.189-0.207 wide), posterior most pair smaller (0.105 and 0.115 long by 0.164 and 0.167 wide). End of haptor armed with two pairs of hooks, large pair 0.108 long, and small pair situated between larger pair 0.016 long.

The specimen of $N$. euthynni described here is slightly smaller than other morphological characterizations made for this species (Millemann, 1956; Castillo-Sánchez, 1994; Justo \& Kohn, 2015), however, arrangement and proportions of suckers of opisthaptor, along with shape of sclerites of haptoral suckers allow us to confirm its specific identity. This monogenean species is commonly found parasitizing little tunas (Scombridae) around the world (Williams \& Bunkley-Williams, 1996). In the Americas, this worm species has previously been recorded from Euthynnus spp. and other scombrid fishes from the United States and Puerto Rico (Hendrix, 1994; Williams \& BunkleyWilliams, 1996), Mexico (Castillo-Sánchez et al., 1997), Galapagos (Cohen et al., 2013), and Brazil (Cohen et al., 2013; Justo \& Kohn, 2015). Present record represents the first for Costa Rica.

Since the high number of monogenean species from other Neotropical places such as Mexico or South America (Luque et al., 2017; Mendoza-Garfias et al., 2017;), a significant increase in the Costa Rican monogenean diversity is expected. There are still a relatively low number of studies about these worms, derived from a very low 


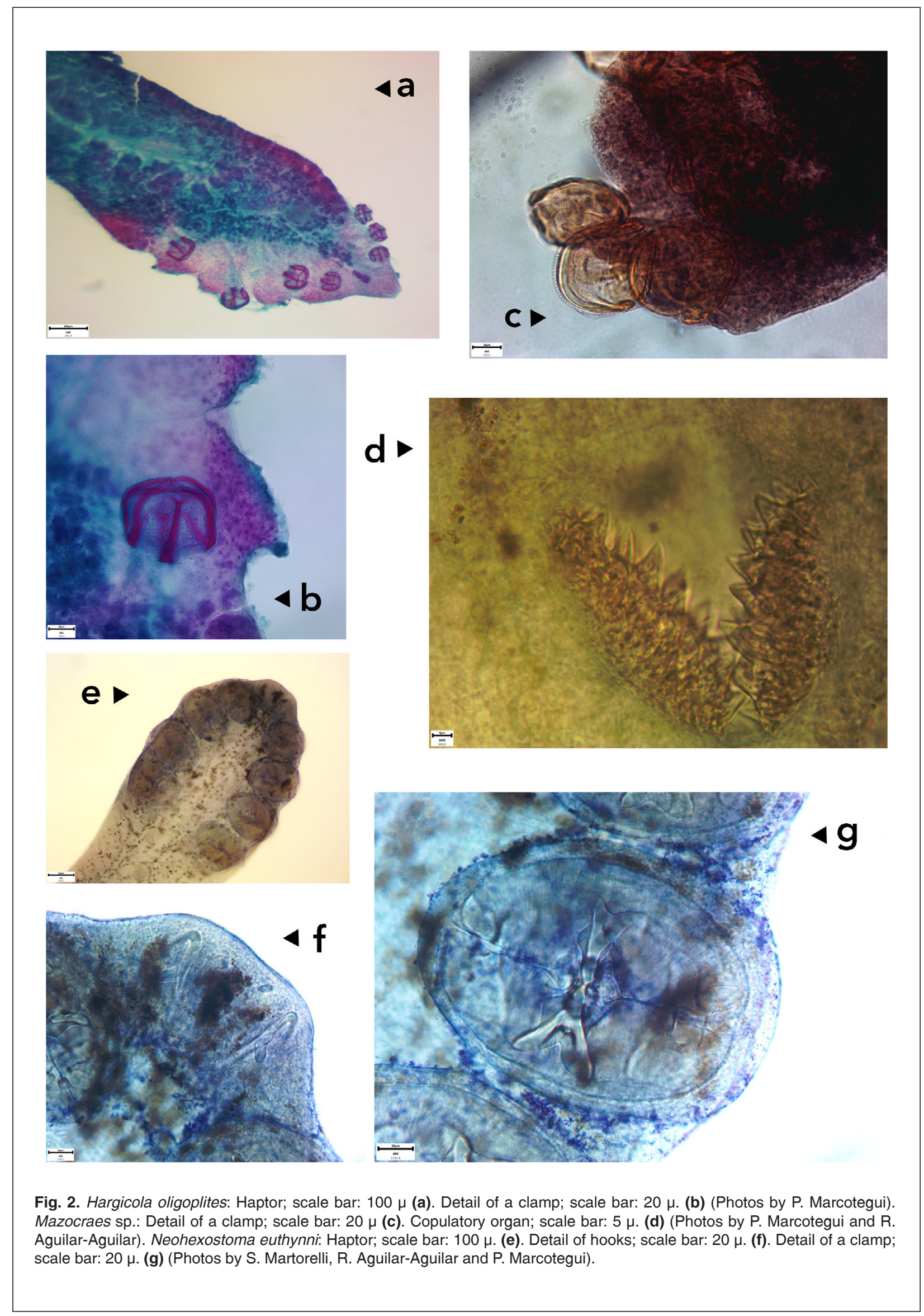

Bol. Soc. Zool. Uruguay (2ª época). 2018. Vol. 27 (1): 7-10 ISSN: 0255-4402 
number of studied fish host species. For this reason, the strengthening of the taxonomic work about helminth species parasitizing fish hosts in the country is widely recommended. In this sense, this study represents an additional piece of information contributing to the inventory of parasite fauna in the region.

\section{ACKNOWLEDGMENTS}

This note was written during a short-term stay of R.A.A. to the Centro de Estudios Parasitológicos y de Vectores, Universidad de La Plata, Argentina. Authors thank Mayvé Romero and Jorge J. Islas Ortega for valuable help editing figures.

\section{REFERENCES}

Bravo-Hollis M. 1989. Monogenea (Van Beneden, 1858) Carus 1863, de peces del Golfo de México y del Mar Caribe XII. Nuevas localidades de colecta de especies conocidas de gastrocotílidos. Anales del Instituto de Biología, Universidad Nacional Autónoma de México. Serie Zoología, 59: 1-14.

Bychowsky B.E. 1961. Monogenean trematodes: their systematics and phylogeny. American Institute of Biological Sciences, Washington. 627 pp.

Castillo-Sánchez E. 1994. Helmintofauna del "barrilete" Euthynnus lineatus (Scombridae), de la Bahía de Chamela, Jalisco. B.Sc. Thesis. Universidad Nacional Autónoma de México, Mexico, D. F. $53 \mathrm{pp}$.

Castillo-Sánchez E., García-Prieto L. \& Pérez-Ponce de León G. 1997. Helmintofauna de Euthynnus lineatus (Perciformes: Scombridae) en Jalisco, México. Revista de Biología Tropical, 45: 12511253.

Chaudhary A., Verma C., Shobna X., Varma M. \& Singh H.S. 2013. A review of monogenean diversity in India: Pathogens of fish diseases. Journal of Coastal Life Medicine, 1: 151-168.

Cohen S.C., Justo M.C.N. \& Kohn A. 2013. South American Monogenoidea parasites of fishes, amphibians and reptiles. Oficina de Livros, Rio de Janeiro. 662 pp.

Hargis Jr. W.J. 1957. Monogenetic trematodes of Gulf of Mexico fishes. Part XIII. The family Gastrocotylidae Price, 1943 (continued). Transactions of the American Microscopical Society, 76: 1-12.

Hendrix S.S. 1994. Marine flora and fauna of the Eastern United States. NOAA Technical Report NMFS 121. U. S. Departament of Commerce, Seattle. 107 pp.

Justo M.C.N. \& Kohn A. 2015. Diversity of Monogenoidea parasitizing scombrid fishes from Rio de Janeiro coast, Brazil. Check List, 11: 1628.

Kohn A., Santos C.P. \& Lebedev B. 1996. Metacamopiella euzeti gen. n., sp. n., and Hargicola oligoplites (Hargis, 1957) (Monogenea: Allodiscocotylidae) from Brazilian fishes. Journal of the Helminthological Society of Washington, 63: 176-180.

Luque J.E., Pereira F.B., Alves P.V., Oliva M.E. \& Timi J.T. 2017. Helminth parasites of South American fishes: current status and characterization as a model for studies of biodiversity. Journal of Helminthology, 91: 150-164.

Mendoza-Garfias B., García-Prieto L. \& Pérez-Ponce de León G. 2017. Checklist of the Monogenea (Platyhelminthes) parasitic in Mexican aquatic vertebrates. Zoosystema, 39: 501-598.

Millemann R.E. 1956. Notes on the genus Hexostoma (Monogenea: Hexostomatidae) with a description of $H$. euthynni Meserve, 1938. Journal of Parasitology, 42: 316-319.

Reed C., MacKenzie K. \& van der Lingen C.D. 2012. Parasites of South African sardines Sardinops sagax, and an assessment of their potential as biological tags. Bulletin-European Association of Fish Pathologists, 32: 41-48.

Rodríguez-Ortiz B., García-Prieto L. \& Pérez-Ponce de León G. 2004. Checklist of the helminth parasites of vertebrates in Costa Rica. Revista de Biología Tropical, 52: 313-354.

Solano-Trejos G. 2010. Colección Helmintológica de Costa Rica (CHCR). En R. Lamothe-Argumedo, C. Damborenea, L. García-Prieto, L. Lunaschi y D. Osorio-Sarabia (Eds.) Guide to Helminthological Collections of Latin America, pp. 33-36. Instituto de Biología, Mexico City, Mexico.

Takemoto R.M., Amato J.F.R., Luque J.L. 1996. Monogenean of leatherjackets, Oligoplites spp. (Osteichthyes: Carangidae), with the description of a new species of Metacompia (Monogenea: Allodiscocotylidae) from the coast of the state of Rio de Janeiro, Brazil. Memórias do Instituto Oswaldo Cruz, 91: 165-172.

Timi J.M., Sardella N.H. \& Etchegoin J.A. 1999. Mazocraeid monogeneans parasitic on engraulid fishes in the Southwest Atlantic. Journal of Parasitology, 85: 28-32.

Williams E.H. \& Bunkley-Williams L. 1996. Parasites of offshore big game fishes of Puerto Rico and the Western Atlantic. University of Puerto Rico, Mayaguez. 382 pp.

Yamaguti, S. 1963. Systema Helminthum Vol. IV. Monogenea and Aspidocotyle. Interscience Publishers, New York. 699 pp.

Fecha de Recepción: 24 de octubre de 2017 Fecha de Aceptación: 16 de febrero de 2018 